\title{
Quantitative Ultrastructural Changes Associated with Lead-coupled Luxury Phosphate Uptake and Polyphosphate Utilization
}

\author{
Linda Sicko-Goad and Diane Lazinsky \\ Great Lakes Research Division, The Institute of Science and Technology, The University of Michigan, Ann Arbor, Michigan 48109
}

\begin{abstract}
Quantitative electron microscopy (stereology) was used to assess the ultrastructural response of three algae representative of the classes Chlorophyceae, Cyanophyceae, and Bacillariophyceae to lead-coupled polyphosphate degradation. The organisms were exposed to a culture medium concentration of $20 \mathrm{ppb} \mathrm{Pb}$ for $3 \mathrm{hr}$ at the time of luxury phosphate uptake and subsequently transferred to phosphorus and lead-free medium. A differential sensitivity was observed as follows: Plectonema $>$ Scenedesmus $>$ Cyclotella. In Plectonema and Scenedesmus, detrimental cytological changes were observed when the polyphosphate relative volume dropped below $0.5 \%$, which was approximately the P-starvation level of polyphosphate. Few significant ultrastructural changes were observed in Cyclotella after one week in P-deficient medium. At this time, the relative volume of polyphosphate was still $1.5 \%$. Although a few significant ultrastructural changes occurred with phosphate deprivation, the greatest numbers of changes occurred in cells that had been exposed to a shortterm ( $3 \mathrm{hr}$ ) low level of $\mathrm{Pb}$. Changes in the relative volume of polyphosphate in all three organisms suggest that Plectonema and Scenedesmus have higher phosphate nutrient requirements than $\mathrm{Cyclo-}$ tella. The ecological implications of metal sequestering by polyphosphate are discussed.
\end{abstract}

Polyphosphate is a ubiquitous long-chained linear polymer present in a wide variety of plants and animals, although it is most often found in bacteria and unicellular algae (Harold 1966; Sicko 1974). In 1975, Crang and Jensen reported the incorporation of titanium into polyphosphate bodies of a bluegreen alga, Anacystis nidulans during the "poly- phosphate overplus" phenomenon which has been described by many authors (Voelz et al. 1966 Jensen and Sicko 1974; Sicko-Goad and Jensen 1976). Subsequent studies revealed that a wide variety of metals $(\mathrm{Pb}, \mathrm{Mg}, \mathrm{Zn}, \mathrm{Cd}, \mathrm{Sr}, \mathrm{Co}, \mathrm{Hg}, \mathrm{Ni}$, $\mathrm{Cu}$ ) were sequestered in polyphosphate bodies in a variety of algae, including blue-greens, greens, and diatoms, both in cultures and in natural assem. blages (Sicko-Goad and Stoermer 1979; Baxter and Jensen 1980; Jensen et al. 1982a, 1982b; Stoermer et al. 1980).

Polyphosphate functions primarily as a phosphorus reserve (Sicko 1974). It can be formed under several distinct nutritional conditions: 1) Restoration of phosphate following a phosphate deficiency (Jensen and Sicko 1974; Sicko-Goad and Jensen 1976); 2) Nutrient imbalance other than phosphorus (Lawry and Jensen 1979; Smith et al. 1954; Spitznagel and Sharp 1959; Voelz et al. 1966); and 3) Disturbance of nucleic acid metabolism (Harold 1966).

The fate and ecological significance of polyphosphate is not well understood. If polyphosphate is metabolized under conditions of limiting phosphorus then, phosphorus limitation should result in polyphosphate degradation and liberation of sequestered metals.

Experiments were conducted to determine both the time sequence and consequences of polyphosphate degradation in three cultured algae and the effects of lead exposure at the time of luxury phosphate uptake. The results of these experiments are presented in this paper.

\section{Materials and Methods}

Three algae were selected for study: Cyclotella meneghiniana (Bacillariophyceae), Scenedesmus quadricauda (Chlorophy- 


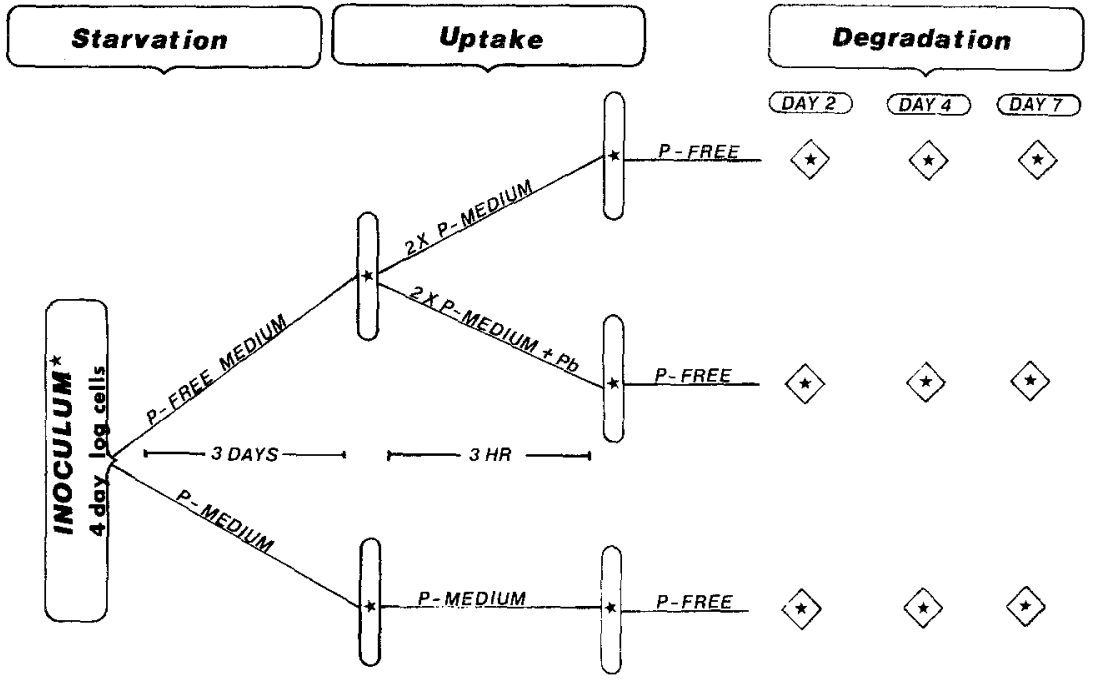

Fig. 1. Experimental flow diagram which defines starvation, uptake, and polyphosphate degradation periods. Sampling times are indicated by stars ceae), and Plectonema boryanum (Cyanophyceae). P. boryanum Gomont (UTEX 581) and $S$. quadricauda (Turp.) Breb. (UTEX 614) were obtained from the Starr Culture Collection (Starr 1978). C. meneghiniana clone $\mathrm{CyOH} 2$ was obtained from Dr. S. S. Kilham who isolated the organism from Lake Ohrid, Yugoslavia in May 1973. Extensive work on phosphorus and silica uptake kinetics on this organism has been reported by Tilman and Kilham (1976). The algae were grown to logarithmic phase at $20^{\circ} \mathrm{C}$ on a $12 / 12$ light-dark cycle. Cyclotella and Scenedesmus were grown in WC medium (Guillard 1975). Plectonema was cultured in modified Fitzgerald's medium (Fitzgerald et al. 1952). Scenedesmus and Cyclotella were initially grown separately in sterile non-toxic tissue culture flasks. However, for the experiment, beginning with transfer to P-free medium before luxury uptake, the cultures were combined and treated as one culture for ease of handling and to minimize experimental variables. Plectonema was maintained separately throughout because of the difference in culture medium.

Since many of our experiments with heavy metals have been conducted with natural phytoplankton assemblages (Sicko-Goad 1982; Sicko-Goad et al. 1986), we felt that combination of the green alga and the diatom as one culture would more closely approximate competitive advantages and interactive effects that might occur in natural waters. Plectonema was not included with the other two algae since it has much higher nutrient requirements and since previous work in Fitzgerald's medium (Jensen et al. (1982a) has established that the alga is capable of sequestering lead.

The algal cells were washed three times in phosphate-free medium prior to the transfer to the P-free medium for starvation (Jensen and Sicko 1974; Sicko-Goad and Jensen 1976). After three days in P-free medium, phosphate was added to a final concentration of approximately $8 \mathrm{mg} \mathrm{PO}_{4} / \mathrm{L}$ (twice the normal level in the growth medium) and filter-sterilized lead nitrate was added with thorough mixing in the $\mathrm{Pb}$ treatment flasks to yield a final $\mathrm{Pb}$ concentration of $20 \mathrm{ppb}$. The cells were incubated under these conditions in a growth chamber for three hr, then washed in phosphate-free medium three times prior to transfer to phosphate- and lead-free medium. All samples were maintained in the phosphate-free medium for seven days. The sampling scheme and times are presented in Figure 1.

A set of control cultures was added to the experimental design to simulate changes that might result from experimental manipu- lations. These cells (Figure 1) were maintained in culture medium with phosphate, but transferred to new phosphate-containing medium at the time the other group of cells was transferred to phosphate-free medium; they are referred to as phosphate-sufficient throughout the text, and also serve as controls for the luxury phosphate uptake cells. Likewise, in the Tables, $\mathbf{P}$ sufficient cells that were transferred to fresh growth medium are referred to as luxury uptake cells to indicate the culture manipulation and transfer.

Aliquots of cell suspension were withdrawn into $50 \mathrm{ml}$ centrifuge tubes. Fixative was added to the tubes to give a final concentration of $1 \%$ glutaraldehyde, $1 \%$ paraformaldehyde, and $0.05 \mathrm{M}$ cacodylate buffer at pH 7.2 (Lazinsky and Sicko-Goad 1979). The cells were fixed for $2 \mathrm{hr}$, rinsed with cacodylate buffer, and then post-fixed in $1 \% \mathrm{OsO}_{4}$ in buffer for $1 \mathrm{hr}$. They were dehydrated in a graded ethanol-propylene oxide series and embedded in Epon (Luft 1961) for transmission electron microscopy. Thin sections were cut with a diamond knife, collected on formvar coated copper grids and stained with aqueous uranyl acetate (Watson 1958). Electron micrographs were taken on a JEOL JEM $100 \mathrm{~B}$ electron microscope operating at $80 \mathrm{kV}$. For quantitative estimates of cell parameters, random sections were obtained through embedded pellets of the algae. Thirty micrographs were obtained at standard magnifications that were species-dependent due to the large differences in cell size among the three algae examined (Sicko-Goad et al. 1977). A transparent $1.0 \mathrm{~cm}$ square sampling lattice was placed over the pictures for estimates of volume density using the grid point-counting techniques (Glagoleff 1983; Chalkley 1943) with precautions taken for sampling unicells (Sicko-Goad et al. 1977; Sicko-Goad and Stoermer 1979; Sicko-Goad 1982; Sicko-Goad et al. 1986).

For X-ray microanalysis, cells were washed with sterile distilled water and dried on formvar coated nylon grids. The grids were examined in a JEOL JSM-U3 SEM operating in the transmitted electron detection mode. The microscope was equipped with a PGT-1000 Alpha-16 x-ray analysis system. The x-ray detector angle was $45^{\circ}$ and the whole cell samples were at a specimen distance of $8 \mathrm{~mm}$. Specimens were scanned for whole cell analyses and inclusions were analyzed in the spot mode.

For ease of discussion and comparison, the following terminology will be used throughout the paper:

Phosphate-sufficient cells: Cells that were maintained continuously in medium containing phosphate. 
Phosphate-starved cells: Cells that were grown in P-sufficient culture medium and subsequently transferred after washing to culture medium containing no phosphate.

Phosphate-uptake cells: Three day phosphate-starved cells that were reinoculated into culture medium containing twice the phosphate concentration of growth medium.

Polyphosphate degradation series cells: Luxury uptake cells sampled at 2, 4, or 7 days after transfer to phosphate-free medium.

To document the effects of phosphate starvation after luxury uptake (polyphosphate degradation period), Dunnett's t-test was used to demonstrate statistically significant differences $(\alpha=$ 0.05 ) between uptake and degradation series cells. To document the cellular changes due to luxury consumption, percent change was determined as the difference between phosphate uptake or degradation cells and phosphate-starved cells. The same analyses were applied to cells that were phosphate-sufficient throughout.

Morphological changes are reported as quantitative volume changes in organelles and cellular compartments determined to be of physiological and morphological significance (Sicko-Goad et al. 1977). Those compartments (ribosomes, Golgi, and occasionally, small vesiculate structures sometimes observed in diatoms, Sicko-Goad 1986), which are difficult to quantify as separate entities on a volume basis due to either their rare occurrence or extremely small volume on a comparative basis, are listed in the Tables as a composite category "Other". In the case of the prokaryote, Plectonema, "Other" is a large number due to the volume of the nucleoplasmic area which is not delineated by membranes as it is in eukaryotes.

\section{Results}

The three organisms tested (a blue-green alga, a green alga, and a diatom) differed in their morphological responses to phosphate uptake and lead exposure. Plectonema was the most sensitive organism in that it only survived in the phosphatefree medium two days after exposure to lead. Scenedesmus survived for 4 days under these conditions, whereas Cyclotella was not greatly affected after 7 days. All three algae responded similarly in control treatments (i.e., those treatments without lead). Cells that were phosphate-sufficient throughout the experiment experienced the fewest morphological changes.

Detailed observations are presented for each species as follows:

Plectonema boryanum: The quantitative ultrastructural data are presented in Tables 2-3. There were significant changes in four cellular compartments during polyphosphate degradation for both the phosphate uptake treatment and the lead-coupled uptake treatment. These were polyphosphate relative volume $\left(\mathrm{V}_{\mathrm{V}}\right)$ and numbers per volume $\left(\mathrm{N}_{\mathrm{V}}\right)$ as well as intrathylakoidal space (IT) $V_{\mathrm{V}}$ and Other $V_{Y}$ (Tables 2-3). However, the direction of change in these two treatments for IT $V_{V}$ and Other $V_{V}$
Table 1. Plectonema boryanum. Quantitative ultrastructural changes associated with culture manipulation on cells maintained under P-sufficient conditions prior to polyphosphate degradation period. Surface area/volume $\left(S_{v}\right)$; relaîive volume $\left(V_{v}\right)$; Number/volume $\left(\mathrm{N}_{\mathrm{v}}\right)$. Results are the mean $\pm 1 \mathrm{~S} . \mathrm{E}$

\begin{tabular}{|c|c|c|c|}
\hline & \multicolumn{3}{|l|}{ Treatments } \\
\hline & $P$ Sufficient & $\begin{array}{l}\text { Luxury } \\
\text { uptake }\end{array}$ & $\begin{array}{l}\text { Degradation } \\
\text { Day } 2\end{array}$ \\
\hline Thylakoid $\left(\mathbf{S}_{v}\right)$ & $\begin{array}{l}17.79 \\
(1.35)\end{array}$ & $\begin{array}{l}17.19 \\
(1.15)\end{array}$ & $\begin{array}{l}14.32 \\
(0.93)\end{array}$ \\
\hline Poly $P\left(N_{v}\right)$ & $\begin{array}{l}156.81 \\
(33.63)\end{array}$ & $\begin{array}{l}201.88 \\
(38.36)\end{array}$ & $\begin{array}{l}197.27 \\
(30.64)\end{array}$ \\
\hline Poly $\mathrm{P}\left(\mathrm{V}_{\mathrm{v}}\right)$ & $\begin{array}{c}0.45 \\
(0.11)\end{array}$ & $\begin{array}{c}1.46 \\
(0.30)\end{array}$ & $\begin{array}{c}1.25 \\
(0.24)\end{array}$ \\
\hline Polyhedral $\left(\mathbb{N}_{v}\right)$ & $\begin{array}{c}2.83 \\
(0.49)\end{array}$ & $\begin{array}{c}2.01 \\
(0.45)\end{array}$ & $\begin{array}{r}4.17^{\mathrm{a}} \\
(0.70)\end{array}$ \\
\hline Polyhedral $\left(V_{v}\right)$ & $\begin{array}{c}2.30 \\
(0.44)\end{array}$ & $\begin{array}{c}1.50 \\
(0.32)\end{array}$ & $\begin{array}{c}2.44 \\
(0.35)\end{array}$ \\
\hline $\begin{array}{c}\text { Intrathylakoidal } \\
\text { Space }\left(\mathrm{V}_{\mathrm{v}}\right)\end{array}$ & $\begin{array}{c}4.91 \\
(0.70)\end{array}$ & $\begin{array}{l}13.14 \\
(1.01)\end{array}$ & $\begin{array}{l}10.06 \\
(1.13)\end{array}$ \\
\hline Other $\left(V_{v}\right)$ & $\begin{array}{l}92.34 \\
(0.73)\end{array}$ & $\begin{array}{l}83.90 \\
(1.11)\end{array}$ & $\begin{array}{l}86.25 \\
(1.33)\end{array}$ \\
\hline
\end{tabular}

a Statistically significant at $\alpha=0.05$. Calculated by Dunnett's t-test (Tables 1-9)

Table 2. P. boryanum. Quantitative changes associated with Pstarvation, luxury uptake, and P-starvation after luxury uptake

\begin{tabular}{|c|c|c|c|}
\hline & \multicolumn{3}{|l|}{ Treatments } \\
\hline & P Starved & $\begin{array}{l}\text { Luxury } \\
\text { uptake }\end{array}$ & $\begin{array}{l}\text { Degradation } \\
\text { Day } 2\end{array}$ \\
\hline Thylakoid $\left(S_{v}\right)$ & $\begin{array}{l}14.57 \\
(0.93)\end{array}$ & $\begin{array}{l}18.34 \\
(1.29)\end{array}$ & $\begin{array}{l}19.64 \\
(1.45)\end{array}$ \\
\hline Poly $\mathbf{P}\left(\mathbf{N}_{\mathrm{v}}\right)$ & $\begin{array}{c}66.38 \\
(17.82)\end{array}$ & $\begin{array}{l}113.91 \\
(12.66)\end{array}$ & $\begin{array}{r}79.75^{\mathrm{a}} \\
(15.40)\end{array}$ \\
\hline Poly $\mathrm{P}\left(\mathrm{V}_{\mathrm{y}}\right)$ & $\begin{array}{c}0.48 \\
(0.15)\end{array}$ & $\begin{array}{c}1.77 \\
(0.19)\end{array}$ & $\begin{array}{r}0.51^{\mathrm{a}} \\
(0.11)\end{array}$ \\
\hline Polyhedra $\left(\mathrm{N}_{\mathrm{v}}\right)$ & $\begin{array}{l}4.37 \\
(0.91)\end{array}$ & $\begin{array}{c}2.71 \\
(0.44)\end{array}$ & $\begin{array}{c}2.18 \\
(0.39)\end{array}$ \\
\hline Polyhedras $\left(V_{v}\right)$ & $\begin{array}{c}3.17 \\
(0.45)\end{array}$ & $\begin{array}{c}2.21 \\
(0.42)\end{array}$ & $\begin{array}{c}2.44 \\
(0.45)\end{array}$ \\
\hline $\begin{array}{c}\text { Intrathylakoidal } \\
\text { Space }\left(V_{v}\right)\end{array}$ & $\begin{array}{l}9.08 \\
(1.24)\end{array}$ & $\begin{array}{c}4.06 \\
(0.74)\end{array}$ & $\begin{array}{r}9.37 a \\
(1.07)\end{array}$ \\
\hline Other $\left(V_{v}\right)$ & $\begin{array}{l}87.26 \\
(1.34)\end{array}$ & $\begin{array}{l}91.95 \\
(0.8 \mathrm{D})\end{array}$ & $\begin{array}{l}87.68^{\mathrm{a}} \\
(1.13)\end{array}$ \\
\hline
\end{tabular}

a Statistically significant at $\alpha=0.05$. Calculated by Dunnett's t-test (Tables 1-9)

were in opposite directions. Cells that were maintained under phosphate sufficient conditions (Table 1 and Figure 1) up to the degradation period experienced only one significant change in the cellular categories examined; this was an increase in polyhedral body (carboxysome) $\mathrm{N}_{\mathrm{y}}$. Comparison of the morphometric data of all three groups of cells on day 2 in $\mathrm{P}$ deficient medium indicates that all cells 
Table 3. $P$. boryanum. Lead-coupled luxury uptake and polyphosphate degradation

\begin{tabular}{|c|c|c|c|}
\hline & \multicolumn{3}{|c|}{ Treatments } \\
\hline & P starved & $\begin{array}{l}\text { Lead-coupled } \\
\text { uptake }\end{array}$ & $\begin{array}{l}\text { Lead-coupled } \\
\text { degradation } \\
\text { Day } 2\end{array}$ \\
\hline Thylakoid $\left(\mathrm{S}_{\mathrm{v}}\right)$ & $\begin{array}{l}14.57 \\
(0.93)\end{array}$ & $\begin{array}{l}15.30 \\
(1.20)\end{array}$ & $\begin{array}{l}14.39 \\
(1.34)\end{array}$ \\
\hline Poly P $\left(N_{v}\right)$ & $\begin{array}{c}66.38 \\
(17.82)\end{array}$ & $\begin{array}{l}396.45 \\
(53.87)\end{array}$ & $\begin{array}{r}62.59^{\mathrm{a}} \\
(12.90)\end{array}$ \\
\hline Poly $P\left(V_{v}\right)$ & $\begin{array}{c}0.48 \\
(0.15)\end{array}$ & $\begin{array}{c}2.06 \\
(0.33)\end{array}$ & $\begin{array}{r}0.37^{\mathrm{a}} \\
(.09)\end{array}$ \\
\hline Polyhedral $\left(\mathrm{N}_{\mathrm{v}}\right)$ & $\begin{array}{c}4.37 \\
(0.91)\end{array}$ & $\begin{array}{c}2.26 \\
(0.49)\end{array}$ & $\begin{array}{c}3.81 \\
(0.87)\end{array}$ \\
\hline Polyhedral $\left(\mathrm{V}_{\mathrm{v}}\right)$ & $\begin{array}{c}3.17 \\
(0.45)\end{array}$ & $\begin{array}{c}1.53 \\
(0.30)\end{array}$ & $\begin{array}{c}1.91 \\
(0.38)\end{array}$ \\
\hline $\begin{array}{c}\text { Intrathylakoidal } \\
\text { Space }\left(V_{v}\right)\end{array}$ & $\begin{array}{c}9.08 \\
(1.24)\end{array}$ & $\begin{array}{l}10.62 \\
(1.29)\end{array}$ & $\begin{array}{r}7.02^{\mathrm{a}} \\
(0.84)\end{array}$ \\
\hline Other $\left(V_{v}\right)$ & $\begin{array}{l}87.26 \\
(1.34)\end{array}$ & $\begin{array}{l}85.79 \\
(1.36)\end{array}$ & $\begin{array}{r}90.70^{\mathrm{a}} \\
(0.88)\end{array}$ \\
\hline
\end{tabular}

a Statistically significant at $\alpha=0.05$. Calculated by Dunnett's t-test (Tables 1-9)

were morphologically similar to the phosphatestarved cells that were used for luxury uptake.

Figure 2 demonstrates that the cells maintained under phosphate-sufficient conditions were still capable of taking up phosphate and experiencing increases in both relative volume and numbers of polyphosphate bodies. These cells also utilized polyphosphate at a reduced rate. Lead-coupled uptake cells formed more polyphosphate and utilized it at a rate greater than the luxury uptake cells that had no lead associated with them.

Since the lead-exposed cells did not survive to 4 days, morphometric sampling was suspended at 2 days. Light microscopic examination of the cells revealed that $\mathrm{P}$-sufficient cells and uptake cells survived for one week under conditions of no available exogenous phosphate.

Scenedesmus quadricauda: In a time frame reference, $S$. quadricauda experienced more morphological changes during the polyphosphate degradation period (Tables 4-6) than during other periods. Unlike Plectonema, Scenedesmus survived the lead-coupled treatments for 4 days. However, the cells that were most susceptible to lead were those exposed to the metal during luxury uptake. This group of cells did not survive beyond 4 days. Organelles were observed in Scenedesmus that resembled lysosomes and autophagic vacuoles (Figures 3-6). Although there is no cytochemical evidence to prove the nature of these organelles, these cellular compartments are listed in the Tables as lysosome-like and autophagic-like vacuoles for ease of discussion and comparison.

Among treatments, the fewest number of significant morphological changes occurred during the polyphosphate degradation period of the luxury uptake cells (Table 5). The cells had the greatest volume of polyphosphate entering the starvation period. The only categories affected were the autophagic-like vacuoles which increased, and polyphosphate $V_{\mathrm{v}}$ which decreased.

The greatest number of changes occurred in the lead-coupled uptake cells (Table 6). Of the ten cellular compartments analyzed, six out of ten were significantly different from the uptake cells after four days in P-deficient medium. Storage materials (primarily starch) are almost doubled with lead exposure. Similarly, autophagic-like vacuoles are almost doubled with lead exposure. Although the $\mathrm{V}_{\mathrm{v}}$ of this inclusion increases with time in all phosphate-free treatments, the increase is much larger with lead. The numbers per volume of autophagiclike vacuoles and lysosome-like inclusions are inversely correlated (Figure 7) on day 4. A significant trend in vacuole reduction (Figure 7 and Table 6) was also observed with lead exposure over the sampled time period.

Cells maintained under P-sufficient conditions were still capable of assimilating phosphate and storing it as polyphosphate, as evidenced by the increase in polyphosphate $\mathrm{V}_{\mathrm{v}}$ and $\mathrm{N}_{\mathrm{v}}$. Like Plectonema, large reductions occurred in these categories on days 2 and 4 . However, lead did not stimulate or depress uptake. The smallest reduction in polyphosphate $\mathrm{V}_{\mathrm{v}}$ during the polyphosphate degradation period was observed in the cells with a previous history of growth under phosphate sufficient conditions.

Cyclotella meneghiniana: Of the three experimental algae, Cyclotella was least affected by the experimental treatments (Tables 7-9). Although there are a few significant changes in several categories, there are no readily discernible trends. Similarly, there are few differences that are discernible by visual observation (Figures 8-9). Autophagiclike vacuoles begin to appear in significant volumes on the seventh day of lead coupled polyphosphate degradation.

Unlike Plectonema and Scenedesmus, the cells in phosphate-sufficient medium did not form additional polyphosphate bodies on transfer to fresh Pmedium (Tables 1,4,7). Polyphosphate degradation also progresses at a slower rate, with $1-1.5 \%$ of the total cell volume occupied by polyphosphate after 7 days incubation in the P-deficient medium. The cultures of Cyclotella exposed to lead survived for greater than two weeks. 


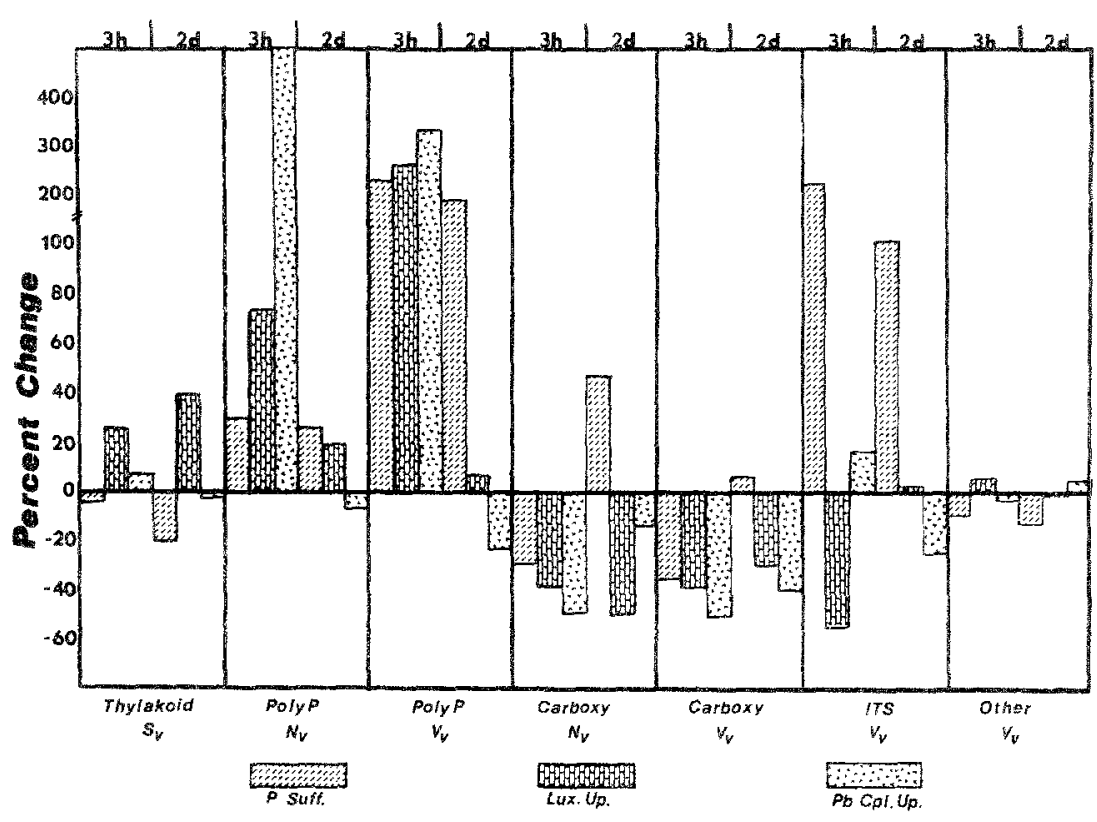

Fig. 2. Percent change in Plectonema boyanum cellular comparments between experimental treatments and controls where the controls are either 3 day P-starved cells (for uptake cells) or 3 day P-sufficient cells. Times sampled are $3 \mathrm{hr}$ post transfer to P-medium and 2 days in P-deficient medium

Table 4. Scenedesmus quadricauda. Quantitative ultrastructural changes associated with culture manipulation of cells maintained under P-sufficient conditions

\begin{tabular}{|c|c|c|c|c|}
\hline & \multicolumn{4}{|l|}{ Treatments } \\
\hline & $P$ sufficient & Luxury uptake & $\begin{array}{l}\text { Degradation } \\
\text { Day } 2\end{array}$ & $\begin{array}{l}\text { Degradation } \\
\text { Day } 4\end{array}$ \\
\hline \multirow[t]{2}{*}{ Storage $\left(\mathrm{V}_{\mathrm{v}}\right)$} & 18.80 & 24.39 & $17.92^{\mathrm{a}}$ & $32.89^{\mathrm{a}}$ \\
\hline & $(2.02)$ & $(1.84)$ & $(1.37)$ & $(2.14)$ \\
\hline \multirow{2}{*}{ Other $\left(V_{v}\right)$} & 64.48 & 58.16 & 63.03 & $44.18^{\mathrm{a}}$ \\
\hline & $(1.66)$ & $(1.45)$ & $(1.18)$ & $(1.88)$ \\
\hline \multirow[t]{2}{*}{ Vacuole $\left(\mathrm{V}_{\mathrm{v}}\right)$} & 0.057 & 0.86 & 2.29 & 1.78 \\
\hline & $(0.067)$ & $(0.35)$ & $(0.47)$ & $(0.78)$ \\
\hline \multirow[t]{2}{*}{ Wall $\left(V_{v}\right)$} & 15.75 & 14.54 & 14.23 & 17.43 \\
\hline & $(0.91)$ & $(0.89)$ & $(0.82)$ & $(1.13)$ \\
\hline \multirow[t]{2}{*}{ Autophagic vacuole-like $\left(V_{V}\right)$} & 0.16 & 0 & 0.96 & $2.02^{\mathrm{a}}$ \\
\hline & $(0.20)$ & 0 & $(0.27)$ & $(0.61)$ \\
\hline $\begin{array}{l}\text { Autophagic vacuole-like } \\
N_{v} / \mu m^{3}\end{array}$ & 0 & 0 & 0.0119 & 0.0178 \\
\hline \multirow[t]{2}{*}{ Polyphosphate $\left(\mathrm{V}_{\mathrm{v}}\right)$} & 0.74 & 1.87 & 0.75 & 1.70 \\
\hline & $(0.17)$ & $(0.41)$ & $(0.26)$ & $(0.58)$ \\
\hline Polyphosphate $\mathrm{N}_{\mathrm{v}} / \mu \mathrm{m}^{3}$ & 0.20 & 0.987 & 0.0518 & 0.0194 \\
\hline \multirow[t]{2}{*}{ Lysosome-like $\left(V_{\mathrm{v}}\right)$} & 0.17 & 0.17 & $0.82^{\mathrm{a}}$ & 0 \\
\hline & $(0.05)$ & $(0.10)$ & $(0.16)$ & 0 \\
\hline Lysosome like $\mathrm{N}_{\mathrm{v}} / \mathrm{\mu m}^{3}$ & 0.115 & 0.0115 & 0.0398 & 0 \\
\hline
\end{tabular}

a Statistically significant at $\alpha=0.05$. Calculated by Dunnett's t-test (Tables $1-9$ )

\section{Discussion}

Many of the quantitative ultrastructural changes reported in this paper are similar to changes reported for heavy metal exposure. For example, Rachlin et al. (1982) found that four hr lead exposure of $P$. boryanum resulted in a decrease in intrathylakoidal space relative volume, which was the same response we obtained at much lower lead levels. Our data on thylakoid surface area to volume ratio with lead exposure are remarkably consistent with
Rachlin's data. Similarly, the decrease in thylakoid $S_{\mathrm{v}}$ ratio with phosphate deficiency has been reported by Jensen and Rachlin (1984) in S. leopoliensis. This significant decrease with phosphate deprivation and metal exposure is consistent with the idea that metabolic processes are reduced under adverse conditions and cells may become dormant. Massalski et al. (1981) reported an increase in intrathylakoid space with copper treatment.

Changes in vacuole volume, presumably a result 
Table 5. S. quadricauda. Quantitative ultrastructural changes associated with P-starvation, luxury uptake, and polyphosphate degradation

\begin{tabular}{|c|c|c|c|c|}
\hline & \multicolumn{4}{|c|}{ Treatments } \\
\hline & P starved & Luxury uptake & $\begin{array}{l}\text { Degradation } \\
\text { Day } 2\end{array}$ & $\begin{array}{l}\text { Degradation } \\
\text { Day } 4\end{array}$ \\
\hline Storage $\left(\mathrm{V}_{\mathrm{v}}\right)$ & $\begin{array}{l}19.36 \\
(1.50)\end{array}$ & $\begin{array}{l}20.83 \\
(1.36)\end{array}$ & $\begin{array}{l}23.23 \\
(1.70)\end{array}$ & $\begin{array}{l}25.00 \\
(2.10)\end{array}$ \\
\hline Other $\left(V_{v}\right)$ & $\begin{array}{l}62.61 \\
(1.79)\end{array}$ & $\begin{array}{l}59.20 \\
(1.43)\end{array}$ & $\begin{array}{l}59.14 \\
(1.85)\end{array}$ & $\begin{array}{l}56.34 \\
(1.95)\end{array}$ \\
\hline Vacuole $\left(\mathrm{V}_{\mathrm{v}}\right)$ & $\begin{array}{c}0.65 \\
(0.23)\end{array}$ & $\begin{array}{c}1.27 \\
(0.35)\end{array}$ & $\begin{array}{c}0.55 \\
(0.24)\end{array}$ & $\begin{array}{c}1.24 \\
(0.49)\end{array}$ \\
\hline Wall $\left(\mathrm{V}_{\mathrm{v}}\right)$ & $\begin{array}{l}14.15 \\
(1.35)\end{array}$ & $\begin{array}{l}14.70 \\
(0.87)\end{array}$ & $\begin{array}{l}14.16 \\
(0.85)\end{array}$ & $\begin{array}{l}14.56 \\
(0.81)\end{array}$ \\
\hline $\begin{array}{l}\text { Autophagic vacuole-like } \\
\left(\mathrm{V}_{\mathrm{v}}\right)\end{array}$ & $\begin{array}{c}1.36 \\
(0.84)\end{array}$ & $\begin{array}{c}0.10 \\
(0.03)\end{array}$ & $\begin{array}{r}1.08^{\mathrm{a}} \\
(0.30)\end{array}$ & $\begin{array}{r}1.67^{\mathrm{a}} \\
(0.43)\end{array}$ \\
\hline Autophagic vacuole-like $\mathrm{N}_{\mathrm{v}} / \mu \mathrm{m}^{3}$ & 0.011 & 0.0017 & 0.0165 & 0.0189 \\
\hline Polyphosphate $\left(\mathrm{V}_{\mathrm{v}}\right)$ & $\begin{array}{l}1.20 \\
(0.41)\end{array}$ & $\begin{array}{c}2.57 \\
(0.31)\end{array}$ & $\begin{array}{r}0.48^{\mathrm{a}} \\
(0.16)\end{array}$ & $\begin{array}{r}0.78^{\mathrm{a}} \\
(0.21)\end{array}$ \\
\hline Polyphosphate $\mathrm{N}_{\mathrm{v}} / \mu \mathrm{m}^{3}$ & 0.053 & 1.49 & 0.0231 & 0.0322 \\
\hline Lysosome-like $\left(\mathrm{V}_{\mathrm{v}}\right)$ & $\begin{array}{c}0.67 \\
(0.13)\end{array}$ & $\begin{array}{c}1.31 \\
(0.31)\end{array}$ & $\begin{array}{c}1.36 \\
(1.10)\end{array}$ & $\begin{array}{c}0.40 \\
(0.25)\end{array}$ \\
\hline Lysosome-like $\mathrm{N}_{\mathrm{v}} / \mu \mathrm{m}^{3}$ & 0.029 & 0.067 & 0.0334 & 0.0170 \\
\hline
\end{tabular}

a Statistically significant at $\alpha=0.05$. Calculated by Dunnett's t-test (Tables $1-9$ )

Table 6. S. quadricauda. Lead-coupled luxury uptake and polyphosphate degradation

\begin{tabular}{|c|c|c|c|c|}
\hline & \multicolumn{4}{|l|}{ Treatments } \\
\hline & P starved & $\begin{array}{l}\text { Lead-coupled } \\
\text { uptake }\end{array}$ & $\begin{array}{l}\text { Lead-coupled } \\
\text { degradation } \\
\text { Day } 2\end{array}$ & $\begin{array}{l}\text { Lead-coupled } \\
\text { degradation } \\
\text { Day } 4\end{array}$ \\
\hline Storage $\left(V_{v}\right)$ & $\begin{array}{l}19.36 \\
(1.50)\end{array}$ & $\begin{array}{l}16.93 \\
(1.42)\end{array}$ & $\begin{array}{l}20.89 \\
(1.51)\end{array}$ & $\begin{array}{l}36.68^{\mathrm{a}} \\
(1.91)\end{array}$ \\
\hline Other $\left(V_{v}\right)$ & $\begin{array}{l}62.61 \\
(1.79)\end{array}$ & $\begin{array}{l}61.97 \\
(1.41)\end{array}$ & $\begin{array}{l}60.92 \\
(1.47)\end{array}$ & $\begin{array}{r}44.95^{\mathrm{a}} \\
(1.76)\end{array}$ \\
\hline Vacuole $\left(V_{v}\right)$ & $\begin{array}{c}0.65 \\
(0.23)\end{array}$ & $\begin{array}{c}1.95 \\
(0.60)\end{array}$ & $\begin{array}{c}0.82 \\
(0.36)\end{array}$ & $\begin{array}{r}0.11^{\mathrm{a}} \\
(0.12)\end{array}$ \\
\hline Wall $\left(V_{v}\right)$ & $\begin{array}{l}14.15 \\
(1.35)\end{array}$ & $\begin{array}{l}15.21 \\
(0.93)\end{array}$ & $\begin{array}{l}15.69 \\
(0.98)\end{array}$ & $\begin{array}{l}13.76 \\
(0.83)\end{array}$ \\
\hline $\begin{array}{l}\text { Autophagic vacuole-like } \\
\left(\mathrm{V}_{\mathrm{v}}\right)\end{array}$ & $\begin{array}{c}1.36 \\
(0.84)\end{array}$ & $\begin{array}{c}0.25 \\
(0.18)\end{array}$ & $\begin{array}{c}0.65 \\
(0.35)\end{array}$ & $\begin{array}{r}4.10^{\mathrm{a}} \\
(0.94)\end{array}$ \\
\hline Autophagic vacuole-like $\mathrm{N}_{\mathrm{v}} / \mu \mathrm{m}^{3}$ & 0.011 & 0.0011 & 0.0178 & 0.0527 \\
\hline Polyphosphate $\left(\mathrm{V}_{\mathrm{v}}\right)$ & $\begin{array}{c}1.20 \\
(0.41)\end{array}$ & $\begin{array}{l}2.65 \\
(0.51)\end{array}$ & $\begin{array}{r}0.42^{\mathrm{a}} \\
(0.13)\end{array}$ & $\begin{array}{r}0.33^{\mathrm{a}} \\
(0.11)\end{array}$ \\
\hline Polyphosphate $N_{v} / \mu m^{3}$ & 0.053 & 0.238 & 0.0372 & 0.0120 \\
\hline Lysosome-like $\left(\mathrm{V}_{\mathrm{v}}\right)$ & $\begin{array}{c}0.67 \\
(0.13)\end{array}$ & $\begin{array}{c}1.02 \\
(0.33)\end{array}$ & $\begin{array}{c}0.59 \\
(0.13)\end{array}$ & $\begin{array}{r}0.07^{\mathrm{a}} \\
(0.04)\end{array}$ \\
\hline Lysosome-like $N_{v} / \mu m^{3}$ & 0.029 & 0.054 & 0.0438 & 0.0023 \\
\hline
\end{tabular}

a Statistically significant at $\alpha=0.05$. Calculated by Dunnett's t-test (Tables $1-9$ )

of changes in membrane permeability (Sicko-Goad 1982), were evident in Scenedesmus. Sublethal concentrations of metals very often produce swollen organelles, dilated membranes and vacuolated cytoplasm which are all indicative of osmotic (and membrane) damage (Sicko-Goad and Stoermer 1979; Sicko-Goad 1982; Smith 1983).
Fasulo et al. (1983) reported reduced chloroplast integrity, enlarged mitochondria, and abnormal vacuolization in chromium treated Euglena. Similarly, Thomas et al. (1980) reported disruption of chloroplast integrity. Associated with membrane damage is the appearance of membranous organelles or multivesiculate bodies that resemble autophagic 


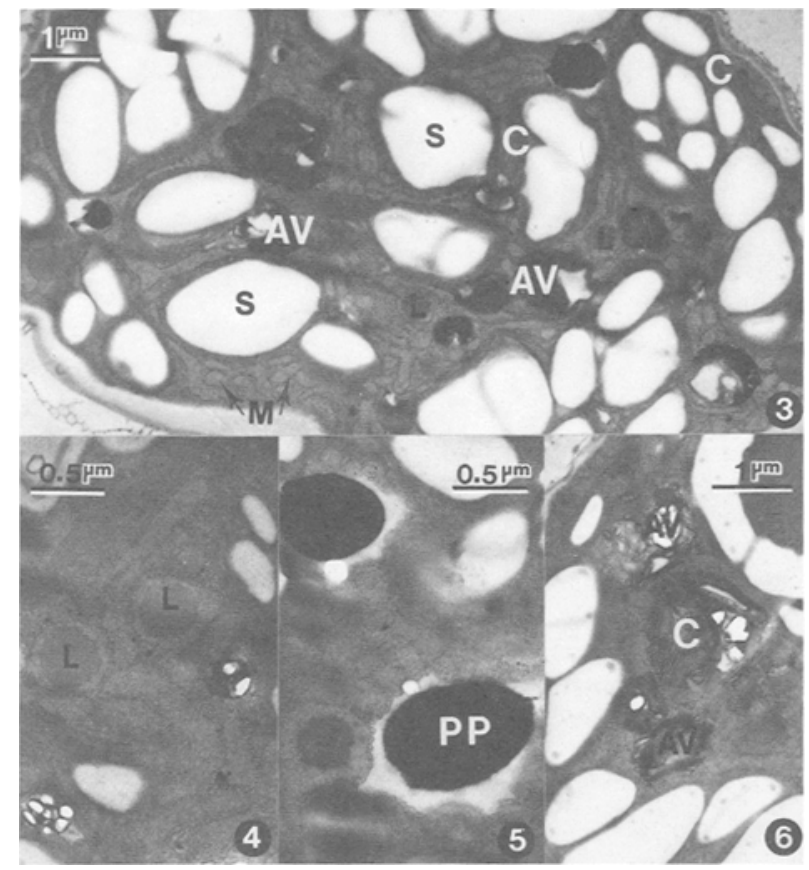

Figs. 3-6. Scenedesmus quadricuuda. 3. Low magnification photo demonstrating numerous chloroplasts $(\mathrm{C})$, storage granules (S), Lysosome-like inclusions (L), mitochondria (M) and autophagic-like vacuoles (AV). Luxury uptake cell, 2 days post transfer to P-free medium. 4. Enlarged view showing lysosome-like inclusions (L). Luxury uptake cells. 5. Enlarged view showing polyphosphate bodies (PP). Luxury uptake cells. 6. Enlarged view showing inclusions resembling residual bodies (AV) and degenerating chloroplasts (C). Lead-coupled luxury uptake, 4 days post transfer to P-free medium

vacuoles or residual bodies (Silverberg 1975; Sicko-Goad and Stoermer 1979; Sicko-Goad 1982; Smith 1983; Sicko-Goad et al. 1986). Roderer (1984) reported that tetraethyl lead exposure of $P_{0}$ terioochromonas malhamensis resulted in a marked increase in lysosomes and residual bodies. These increases were much more pronounced than when the alga was exposed to inorganic lead (Roderer 1981).

Of the three organisms tested, Plectonema boryanum is known by definitive methods of X-ray microanalysis to be capable of sequestering lead and other heavy metals in polyphosphate (Jensen $e t$ al. 1982a). The other two algae, Scenedesmus and $C y$ clotella, were chosen to be representative species of algae common in the Laurentian Great Lakes. Although $\mathrm{Pb}$ was not accumulated to a concentration detectable by $\mathrm{X}$-ray microanalysis in the experimental organisms, the possibility exists that we were at or below the limits of detection, since the organisms were only exposed to $20 \mathrm{ppb} \mathrm{Pb}$ for a period of three hr and, thus, we cannot rule out metal sequestering. Jensen et al. (1982b) have dem- onstrated this sequestering phenomenon in other species of the divisions Chlorophyceae and Bacillariophyceae, although at higher metal concentrations.

Jensen et al. (1982a, 1982b) have speculated that sequestering or compartmentalization of heavy metals in polyphosphate bodies may serve a dual purpose in cells by providing a storage site for essential metals and also by acting as a detoxification mechanism. Sequestering heayy metals may be an important ecological issue for two reasons. First, the detoxification mechanism may remove the metals from the active metabolic pool, thereby delaying metal effects. Second, the eventual fate of the metal may be dependent on phosphate nutrient status. Our results suggest that the effects of lead may be removed both spatially and temporally from the source of the metals. The results are also consistent with the findings of Bates et al. (1983) and Kuwabara (1985) who speculated that $\mathrm{Zn}$ may be stored intracellularly in polyphosphate bodies, and as cells metabolize $\mathrm{P}$ for growth, the $\mathrm{Zn}$ is dissociated and reaches an intracellular toxic threshold level preventing further growth and metabolism of P. Interactive or synergistic effects of nutrients with heavy metals have also been reported by SickoGoad et al. (1986).

Previous studies in our laboratory (Stoermer et al. 1980; Sicko-Goad and Lazinsky 1982) suggested that incorporation of lead in polyphosphate bodies may be an important mechanism for the movement of metals, especially lead, in aquatic ecosystems. This suggestion was based on the observation of lead in polyphosphate bodies of naturally-occurring phytoplankton species coupled with the observation that metals were sequestered in species that are known to survive transport from the eutrophic waters of Saginaw Bay into the less eutrophic waters of Southern Lake Huron. Subsequent studies (Sicko-Goad and Lazinsky 1982 and Sicko-. Goad, unpublished observations) revealed that in a systematic study of polyphosphate abundance in Saginaw Bay and Southern Lake Huron, fewer polyphosphate bodies were found in algal populations in the open waters of the Lake, where the phosphate concentration is substantially reduced.

The results presented in this paper also suggest that a differential sensitivity to lead exists among the three organism tested based on the length of survival after a very short-term, low dose exposure. It is interesting to note that moribund cells were observed in the lead treatments after the polyphosphate relative volume dropped to approximately $0.5 \%$ for both Scenedesmus and Plectonema, while these same changes were not observed in Cyclotella after one week in phosphate 


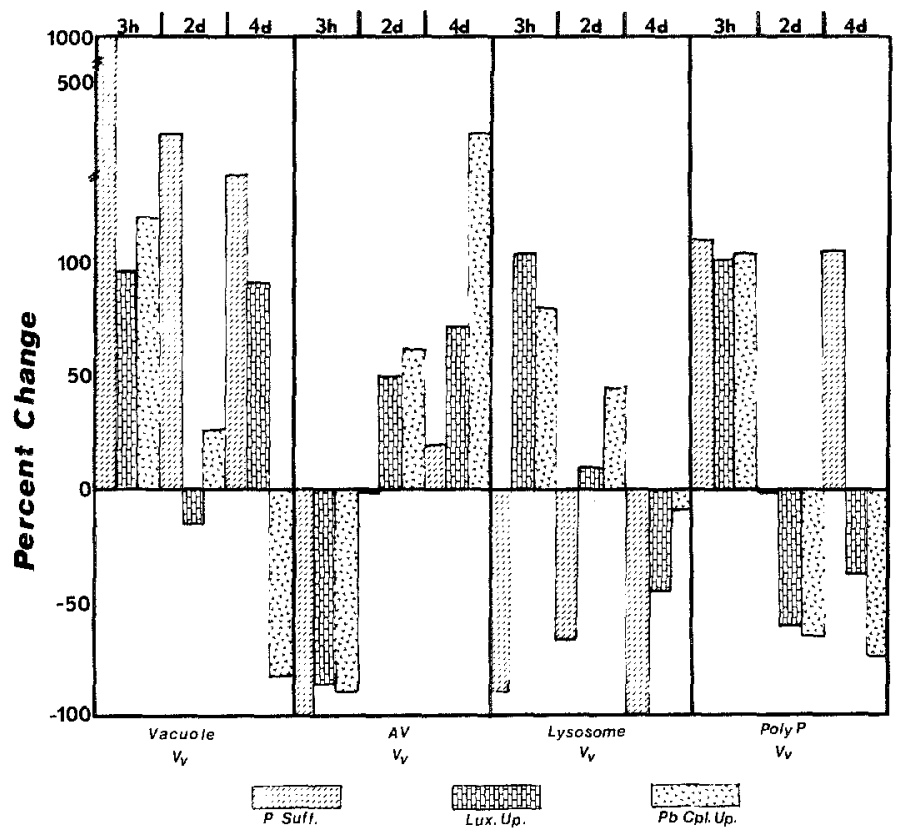

Fig. 7. Percent change in four cellular compartments of Scenedesmus quadricauda. Note inverse correlation between $\mathrm{AV}$ and lysosome relative volume. Also note larger utilization of polyphosphate (negative change) by luxury uptake and lead-coupled uptake cells

Table 7. Cyclotella meneghiniana. Quantitative ultrastructural changes associated with culture transfers of P-sufficient cells

\begin{tabular}{|c|c|c|c|c|c|}
\hline & \multicolumn{5}{|l|}{ Treatments } \\
\hline & P sufficient & Luxury uptake & $\begin{array}{l}\text { Degradation } \\
\text { Day } 2\end{array}$ & $\begin{array}{l}\text { Degradation } \\
\text { Day } 4\end{array}$ & $\begin{array}{l}\text { Degradation } \\
\text { Day } 7\end{array}$ \\
\hline Chloroplast $\left(\mathrm{V}_{\mathrm{v}}\right)$ & $\begin{array}{l}26.15 \\
(2.00)\end{array}$ & $\begin{array}{l}24.18 \\
(2.09)\end{array}$ & $\begin{array}{l}20.87 \\
(2.02)\end{array}$ & $\begin{array}{l}24.27 \\
(1.78)\end{array}$ & $\begin{array}{l}22.96 \\
(1.72)\end{array}$ \\
\hline Mitochondria $\left(\mathrm{V}_{\mathrm{v}}\right)$ & $\begin{array}{c}2.77 \\
(0.43)\end{array}$ & $\begin{array}{c}2.87 \\
(0.52)\end{array}$ & $\begin{array}{c}1.54 \\
(0.45)\end{array}$ & $\begin{array}{c}2.84 \\
(0.69)\end{array}$ & $\begin{array}{c}2.83 \\
(0.55)\end{array}$ \\
\hline Mitochondria $\mathrm{N}_{\mathrm{v}} / \mu \mathrm{m}^{3}$ & .09 & .12 & .08 & .05 & .07 \\
\hline Mitochondria $S_{v}\left(\mu \mathrm{m}^{2} / \mu \mathrm{m}^{3}\right)$ & 7.90 & 10.70 & 9.50 & 6.34 & 6.63 \\
\hline Storage $\left(V_{v}\right)$ & $\begin{array}{c}3.44 \\
(0.70)\end{array}$ & $\begin{array}{c}3.56 \\
(1.49)\end{array}$ & $\begin{array}{c}1.56 \\
(0.66)\end{array}$ & $\begin{array}{c}1.81 \\
(0.56)\end{array}$ & $\begin{array}{l}0.53^{\mathrm{a}} \\
0.22\end{array}$ \\
\hline Nucleus $\left(V_{v}\right)$ & $\begin{array}{l}11.58 \\
(2.09)\end{array}$ & $\begin{array}{c}8.24 \\
(1.85)\end{array}$ & $\begin{array}{l}12.06 \\
(2.70)\end{array}$ & $\begin{array}{l}12.75 \\
(2.09)\end{array}$ & $\begin{array}{l}13.24 \\
(2.72)\end{array}$ \\
\hline Other $\left(V_{v}\right)$ & $\begin{array}{l}17.54 \\
(1.50)\end{array}$ & $\begin{array}{l}22.63 \\
(1.61)\end{array}$ & $\begin{array}{l}21.14 \\
(1.60)\end{array}$ & $\begin{array}{l}23.37 \\
(1.39)\end{array}$ & $\begin{array}{l}16.97^{\mathrm{a}} \\
(1.16)\end{array}$ \\
\hline Vacuole $\left(V_{v}\right)$ & $\begin{array}{l}19.87 \\
(1.89)\end{array}$ & $\begin{array}{l}22.32 \\
(2.04)\end{array}$ & $\begin{array}{l}25.20 \\
(2.29)\end{array}$ & $\begin{array}{l}20.04 \\
(1.81)\end{array}$ & $\begin{array}{l}26.49 \\
(2.05)\end{array}$ \\
\hline Frustule $\left(\mathrm{V}_{\mathrm{v}}\right)$ & $\begin{array}{l}15.80 \\
(1.52)\end{array}$ & $\begin{array}{l}14.08 \\
(0.95)\end{array}$ & $\begin{array}{l}15.31 \\
(1.02)\end{array}$ & $\begin{array}{l}13.09 \\
(0.79)\end{array}$ & $\begin{array}{l}15.72 \\
(0.92)\end{array}$ \\
\hline Frustule $S_{v}\left(\mu \mathrm{m}^{2} / \mu \mathrm{m}^{3}\right)$ & 1.31 & 1.29 & 1.24 & 1.31 & 1.11 \\
\hline $\begin{array}{l}\text { Autophagic Vacuole-like } \\
\left(V_{v}\right)\end{array}$ & $\begin{array}{c}0.25 \\
(0.15)\end{array}$ & $\begin{array}{c}0.18 \\
(0.08)\end{array}$ & $\begin{array}{c}0 \\
(0)\end{array}$ & $\begin{array}{c}0 \\
(0)\end{array}$ & $\begin{array}{l}0.26 \\
0.14\end{array}$ \\
\hline Polyphosphate $\left(\mathrm{V}_{\mathrm{v}}\right)$ & $\begin{array}{c}2.57 \\
(0.59)\end{array}$ & $\begin{array}{c}1.94 \\
(0.37)\end{array}$ & $\begin{array}{c}2.32 \\
(0.49)\end{array}$ & $\begin{array}{c}1.82 \\
(0.27)\end{array}$ & $\begin{array}{c}1.03 \\
(0.30)\end{array}$ \\
\hline
\end{tabular}

a Statistically significant at $\alpha=0.05$. Calculated by Dunnett's t-test (Tables $1-9$ )

deficient medium. Under the same culture conditions, the relative volume of polyphosphate in $\mathrm{Cy}$ clotella was not significantly diminished. However, the possibility still exists that Scenedesmus sequestered the metal and made less available for Cyclotella, which is why we observed fewer morphological changes. Another possibility exists that in $C y$ - clotella, the metal may have been bound to the organic coating of the siliceous frustule and never reached the intracellular components. Such results have been reported by Conway (1978) and Lindahl et al. (1983). The absence of definitive results with the X-ray microanalysis at the low metal levels leaves this area open to speculation. In any case, 
Table 8. C. meneghiniana. Ultrastructural changes associated with luxury uptake and polyphosphate degradation

\begin{tabular}{|c|c|c|c|c|c|}
\hline & \multicolumn{5}{|l|}{ Treatments } \\
\hline & P starved & Luxury uptake & $\begin{array}{l}\text { Degradation } \\
\text { Day } 2\end{array}$ & $\begin{array}{l}\text { Degradation } \\
\text { Day } 4\end{array}$ & $\begin{array}{l}\text { Degradation } \\
\text { Day } 7\end{array}$ \\
\hline Chloroplast $\left(\mathrm{V}_{\mathrm{v}}\right)$ & $\begin{array}{l}20.18 \\
(2.07)\end{array}$ & $\begin{array}{l}22.45 \\
(1.98)\end{array}$ & $\begin{array}{l}20.23 \\
(2.14)\end{array}$ & $\begin{array}{l}20.45 \\
(2.35)\end{array}$ & $\begin{array}{l}24.09 \\
(2.08)\end{array}$ \\
\hline Mitochondria $\left(V_{v}\right)$ & $\begin{array}{c}2.58 \\
(0.59)\end{array}$ & $\begin{array}{c}4.03 \\
(0.90)\end{array}$ & $\begin{array}{c}2.17 \\
(0.59)\end{array}$ & $\begin{array}{c}3.24 \\
(0.65)\end{array}$ & $\begin{array}{c}2.37 \\
(0.48)\end{array}$ \\
\hline Mitochondria $\mathrm{N}_{\mathrm{v}} / \mu \mathrm{m}^{3}$ & .10 & .07 & .05 & .10 & .07 \\
\hline Mitochondria $S_{v}\left(\mu \mathrm{m}^{2} / \mu \mathrm{m}^{3}\right)$ & 9.45 & 6.98 & 7.06 & 8.97 & N.C. \\
\hline Storage $\left(V_{\mathrm{v}}\right)$ & $\begin{array}{c}4.95 \\
(1.02)\end{array}$ & $\begin{array}{c}2.99 \\
(0.82)\end{array}$ & $\begin{array}{c}2.67 \\
(0.93)\end{array}$ & $\begin{array}{c}1.49 \\
(0.30)\end{array}$ & $\begin{array}{r}1.77 \\
0.77\end{array}$ \\
\hline Nucleus $\left(V_{v}\right)$ & $\begin{array}{l}16.12 \\
(2.94)\end{array}$ & $\begin{array}{l}14.20 \\
(2.84)\end{array}$ & $\begin{array}{l}12.38 \\
(2.38)\end{array}$ & $\begin{array}{l}12.83 \\
(2.45)\end{array}$ & $\begin{array}{l}11.41 \\
(2.66)\end{array}$ \\
\hline Other $\left(V_{v}\right)$ & $\begin{array}{l}20.27 \\
(2.35)\end{array}$ & $\begin{array}{l}18.41 \\
(1.38)\end{array}$ & $\begin{array}{l}21.03 \\
(1.74)\end{array}$ & $\begin{array}{l}21.13 \\
(1.60)\end{array}$ & $\begin{array}{l}16.58 \\
\{1.24)\end{array}$ \\
\hline Vacuole $\left(V_{v}\right)$ & $\begin{array}{l}20.03 \\
(2.42)\end{array}$ & $\begin{array}{l}18.74 \\
(1.83)\end{array}$ & $\begin{array}{l}24.59 \\
(1.90)\end{array}$ & $\begin{array}{l}24.53 \\
(2.12)\end{array}$ & $\begin{array}{l}29.57^{a} \\
(1.95)\end{array}$ \\
\hline Frustule $\left(\mathrm{V}_{\mathrm{v}}\right)$ & $\begin{array}{l}14.24 \\
(1.26)\end{array}$ & $\begin{array}{l}15.75 \\
(1.32)\end{array}$ & $\begin{array}{l}14.55 \\
(1.11)\end{array}$ & $\begin{array}{l}13.45 \\
(1.08)\end{array}$ & $\begin{array}{l}12.93 \\
(0.73)\end{array}$ \\
\hline Frustule $S_{v}\left(\mu \mathrm{m}^{2} / \mu \mathrm{m}^{3}\right)$ & 1.37 & 1.26 & 1.32 & 1.15 & N.C. ${ }^{b}$ \\
\hline $\begin{array}{l}\text { Autophagic Vacuole-like } \\
\left(V_{v}\right)\end{array}$ & $\begin{array}{c}0.13 \\
(0.07)\end{array}$ & $\begin{array}{c}0.16 \\
(0.08)\end{array}$ & $\begin{array}{c}0.05 \\
(0.07)\end{array}$ & $\begin{array}{c}0.08 \\
(0.10)\end{array}$ & $\begin{array}{c}0.09 \\
(0.07)\end{array}$ \\
\hline Polyphosphate $\left(\mathrm{V}_{\mathrm{v}}\right)$ & $\begin{array}{c}1.48 \\
(0.53)\end{array}$ & $\begin{array}{c}3.25 \\
(0.57)\end{array}$ & $\begin{array}{c}2.33 \\
(0.37)\end{array}$ & $\begin{array}{c}2.79 \\
(0.53)\end{array}$ & $\begin{array}{r}1.19^{\mathrm{a}} \\
(0.35)\end{array}$ \\
\hline
\end{tabular}

a Statistically significant at $\alpha=0.05$. Calculated by Dunnett's t-test (Tables 1-9)

b Not calculated

Table 9. C. meneghiniana. Lead-coupled luxury uptake and polyphosphate degradation

\begin{tabular}{|c|c|c|c|c|c|}
\hline & \multicolumn{5}{|l|}{ Treatments } \\
\hline & P starved & $\begin{array}{l}\text { Lead-coupled } \\
\text { Uptake }\end{array}$ & $\begin{array}{l}\text { Lead-coupled } \\
\text { degradation } \\
\text { Day } 2\end{array}$ & $\begin{array}{l}\text { Lead-coupled } \\
\text { degradation } \\
\text { Day } 4\end{array}$ & $\begin{array}{l}\text { Lead-coupled } \\
\text { degradation } \\
\text { Day } 7\end{array}$ \\
\hline Chloroplast $\left(\mathrm{V}_{\mathrm{v}}\right)$ & $\begin{array}{l}20.18 \\
(2.07)\end{array}$ & $\begin{array}{l}19.29 \\
(1.77)\end{array}$ & $\begin{array}{l}20.92 \\
(1.66)\end{array}$ & $\begin{array}{l}21.91 \\
(2.18)\end{array}$ & $\begin{array}{l}24.10 \\
(1.95)\end{array}$ \\
\hline Mitochondria $\left(V_{v}\right)$ & $\begin{array}{c}2.58 \\
(0.59)\end{array}$ & $\begin{array}{c}3.05 \\
(0.61)\end{array}$ & $\begin{array}{c}2.42 \\
(0.39)\end{array}$ & $\begin{array}{c}1.87 \\
(0.49)\end{array}$ & $\begin{array}{c}2.38 \\
(0.54)\end{array}$ \\
\hline Mitochondria $\mathrm{N}_{\mathrm{v}} / \mu \mathrm{m}^{3}$ & .10 & .09 & .09 & .10 & .08 \\
\hline $\begin{array}{l}\text { Mitochondria } S_{y} \\
\left(\mu m^{2} / \mu m^{3}\right)\end{array}$ & 9.45 & 9.25 & 8.17 & 10.91 & N.C. ${ }^{b}$ \\
\hline Storage $\left(\mathrm{V}_{\mathrm{v}}\right)$ & $\begin{array}{c}4.95 \\
(1.02)\end{array}$ & $\begin{array}{c}4.73 \\
(1.10)\end{array}$ & $\begin{array}{c}2.58 \\
(0.75)\end{array}$ & $\begin{array}{r}1.35^{\mathrm{a}} \\
(0.65)\end{array}$ & $\begin{array}{l}2.89 \\
0.81\end{array}$ \\
\hline Nucleus $\left(V_{v}\right)$ & $\begin{array}{l}16.12 \\
(2.94)\end{array}$ & $\begin{array}{l}14.73 \\
(2.68)\end{array}$ & $\begin{array}{l}12.53 \\
(2.58)\end{array}$ & $\begin{array}{l}12.62 \\
(3.07)\end{array}$ & $\begin{array}{l}12.73 \\
(2.17)\end{array}$ \\
\hline Other $\left(V_{v}\right)$ & $\begin{array}{l}20.27 \\
(2.35)\end{array}$ & $\begin{array}{l}20.06 \\
(1.23)\end{array}$ & $\begin{array}{l}20.76 \\
(0.87)\end{array}$ & $\begin{array}{l}21.00 \\
(1.62)\end{array}$ & $\begin{array}{l}16.66 \\
(0.91)\end{array}$ \\
\hline Vacuole $\left(V_{v}\right)$ & $\begin{array}{l}20.03 \\
(2.42)\end{array}$ & $\begin{array}{l}21.26 \\
(2.38)\end{array}$ & $\begin{array}{l}25.61 \\
(2.08)\end{array}$ & $\begin{array}{l}24.43 \\
(2.32)\end{array}$ & $\begin{array}{l}25.13 \\
2.10)\end{array}$ \\
\hline Frustule $\left(\mathrm{V}_{\mathrm{v}}\right)$ & $\begin{array}{l}14.24 \\
(1.26)\end{array}$ & $\begin{array}{l}14.32 \\
(0.68)\end{array}$ & $\begin{array}{l}12.56 \\
(0.82)\end{array}$ & $\begin{array}{l}14.47 \\
(1.06)\end{array}$ & $\begin{array}{l}13.86 \\
(1.00)\end{array}$ \\
\hline $\begin{array}{l}\text { Frustule } S_{v} \\
\qquad\left(\mu \mathrm{m}^{2} / \mu \mathrm{m}^{3}\right)\end{array}$ & 1.37 & 1.26 & 1.16 & 1.22 & N.C. ${ }^{b}$ \\
\hline $\begin{array}{l}\text { Autophagic Vacuole-iike } \\
\left(V_{v}\right)\end{array}$ & $\begin{array}{c}0.13 \\
(0.07)\end{array}$ & $\begin{array}{c}0.32 \\
(0.15)\end{array}$ & $\begin{array}{c}0 \\
(0)\end{array}$ & $\begin{array}{c}0.03 \\
(0.03)\end{array}$ & $\begin{array}{r}0.67^{\mathrm{a}} \\
(0.29)\end{array}$ \\
\hline Polyphosphate $\left(V_{v}\right)$ & $\begin{array}{c}1.48 \\
(0.53)\end{array}$ & $\begin{array}{c}2.23 \\
(0.49)\end{array}$ & $\begin{array}{c}2.61 \\
(0.47)\end{array}$ & $\begin{array}{c}2.29 \\
(0.39)\end{array}$ & $\begin{array}{r}1.58 \\
(0.31)\end{array}$ \\
\hline
\end{tabular}

a Statistically significant at $\alpha=0.05$. Calculated by Dunnett's t-test (Tables 1-9)

b Not calculated 


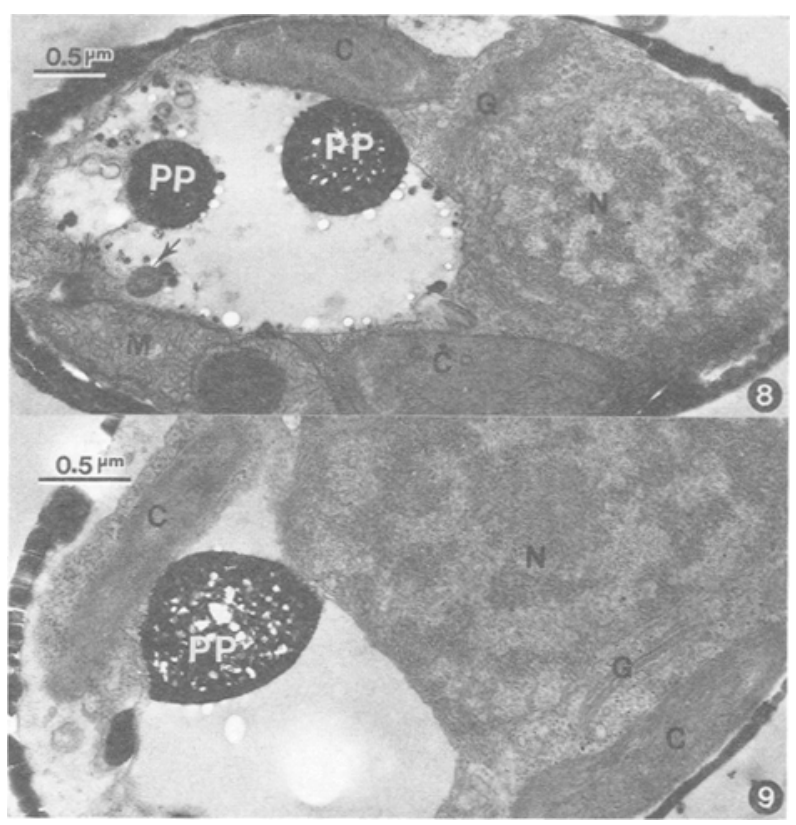

Figs. 8-9. Cyclotella meneghiniana. 8. Luxury uptake cell. Note large polyphosphate bodies (PP) in vacuole, and small AVlike inclusions (arrows). Mitochondria (M), chloroplast (C), nucleus (N), and Golgi (G) appear normal. 9. Lead-coupled uptake cells, 7 days post transfer to P-free medium. Appearance of organelles is very similar to those in Figure 8

for our experimental conditions, Cyclotella was less sensitive to the presence of lead.

The insignificant number of cytological changes observed in Cyclotella might also be explained by an inherent competitive ability of the diatom to rapidly recycle phosphorus and preferentially utilize exogenous phosphorus if it is available. Since the diatom and green alga were combined in one culture flask and Scenedesmus survived for only four days under the experimental conditions, it is possible that the phosphorus released from the moribund cells was sufficient to prevent mobilization of phosphate from polyphosphate. The data also demonstrate that Plectonema and Scenedesmus have greater phosphorus requirements and consequently mobilize polyphosphate more quickly than Cyclotella. This is based on the fact that even in cultures maintained under seemingly P-sufficient conditions, Plectonema and Scenedesmus formed more polyphosphate after transfer to fresh medium, and transfer of luxury uptake cells to P-free medium resulted in the demise of the organisms more quickly than in Cyclotella. This would further substantiate field observation of fewer polyphosphate bodies in algal populations of open lake waters where phosphorus supplies are substantially reduced.

In terms of significant numbers of morphological changes and relative sensitivity to lead, the algae tested would be rated as follows: Plectonema $>$ Scenedesmus $>$ Cyclotella. The morphological changes and culture decline were most evident in lead-coupled polyphosphate degradation, leading us to believe that the lead was associated with the polyphosphate, and that this lead was made available to the cells upon utilization of the polyphosphate. No apparent changes were observed until the internal stores of polyphosphate dropped to or below the maintenance levels of polyphosphate found in actively growing, but P-starved cells.

Acknowledgments. Supported by Grant R-R807516010 from the Office of Exploratory Research, United States Environmental Protection Agency. We are grateful to Dr. S. S. Kilham for supplying the culture of $C$. meneghiniana. Contribution No. 446 of the Great Lakes Research Division.

\section{References}

Bates SS, Letourneau M, Tessier A, Campbell PG (1983) Variation in zinc adsorption and transport during growth of Chlamydomonas variabilis (Chlorophyceae) in batch culture with daily additions of zinc. Can J Fish Aquat Sci 40:895904

Baxter M, Jensen TE (1980) Uptake of magnesium, strontium, barium, and manganese by Plectonema boryanum (Cyanophyceae) with special reference to polyphosphate bodies. Protoplasma 104:81-89

Chalkley HW (1943) Methods for the quantitative morphologic analysis of tissues. J Nat Cancer Inst 4:47-53

Conway HL (1978) Sorption of arsenic and cadmium and their effects on growth, micronutrient utilization, and photosynthetic pigment composition of Asterionella formosa. J Fish Res Board Can 35:286-294

Crang RE, Jensen TE (1975) Incorporation of titanium in polyphosphate bodies of Anacystis nidulans. J Cell Biol 67:80a

Fasulo MP, Bassi M, Donini A (1983) Cytotoxic effects of hexavalent chromium in Euglena gracilis. II. Physiological and ultrastructural studies. Protoplasma 114:35-43

Fitzgerald GP, Gerloff GC, Skoog F (1952) Studies on chemicals with selective toxicity to blue-green algae. Sewage Ind Wastes 24:888-896

Glagoleff AA (1933) On the geometrical methods of quantitative mineralogic analysis of rocks. Trans Inst Econ Mineral Metal, Vol 59, Moscow

Guillard RRL (1975) Culture of phytoplankton for feeding marine invertebrates, In: Smith, WL Chanley MH (eds) Culture of marine invertebrate animals. Plenum, New York, pp $39-59$

Harold FM (1966) Inorganic polyphosphates in biology: Structure, metabolism, and function. Bact Rev 30:772-794

Jensen TE, Rachlin JW (1984) Effect of varying sulphur deficiency on structural components of a cyanobacterium Synechococcus leopoliensis: A morphometric study. Cytobios 41:35-46

Jensen TE, Sicko LM (1974) Phosphate metabolism in bluegreen algae. I. Fine structure of the "polyphosphate overplus" phenomenon in Plectonema boryanum. Can $\mathbf{J}$ Microbiol 20:1235-1240 
Jensen TE, Baxter M, Rachlin JW, Jani V (1982a) Uptake of heavy metals by Plectonema boryanum (Cyanophyceae) into cellular compartments, especially polyphosphate bodies: An X-ray energy dispersive study. Environ Pollut Ser A 27:119-127

Jensen TE, Rachlin JW, Jani V, Warkentine B (1982b) An X-ray energy dispersive study of cellular compartmentalization of lead and zinc in Chlorella saccharophila (Chlorophyta), $\mathrm{Na}$ vicula incerta and Nitzschia closterium (Bacillariophyta). Environ Exp Bot 22-319-328

Kuwabara JS (1985) Phosphorus-zinc interactive effects on growth by Selenastrum capricomutum (Chlorophyta). Environ Sci Technol 19:417-421

Lawry NH, Jensen TE (1979) Deposition of condensed phosphate as an effect of varying sulfur deficiency in the cyanobacterium Synechococcus sp (Anacystis nidulans). Arch Microbiol 102:1-7

Lazinsky D, Sicko-Goad L (1979) Paraformaldehyde-giutaraldehyde as a routine phytoplankton fixative. Micron 10:49-50

Lindahl G, Wallstrom K, Roomans GM, Pedersen M (1983) $\mathrm{X}$-ray microanalysis of planktic diatoms in in situ srudies of metal pollution. Bot Mar 26:367-373

Luft JH (1961) Improvements of epoxy embedding methods. J Biophys Biochem Cytol 9:409-414

Massalski A, Laube VM, Kushner DJ (1981) Effects of cadmium and copper on the ultrastructure of Ankistrodesmus braunit and Anabaena 7120. Microb Ecol 7:183-193

Rachlin JW, Jensen TE, Baxter M, Jani V (1982) Utilization of morphometric analysis in evaluating response of Plectonema boryanum (Cyanophyceae) to exposure to eight heavy metals. Arch Environ Contam Toxicol 11:323-333

Roderer $G$ (1981) On the toxic effects of tetraethyl lead and its derivatives on the Chrysophyte Poterioochromonas malhamensis. II. Triethyl lead, diethyl lead, and inorganic lead. Environ Res 25:361-371

- (1984) On the toxic effects of tetraethyl lead and its deriv. atives on the Chrysophyte Poterioochromonas malhamensis. V. Electron microscopical studies. Environ Exp Bot 24:17-30

Sicko LM (1974) Physiological and cytological aspects of phosphate metabolism in the blue-green alga Plectonema boryanum. PhD Dissertation. City University of New York, New York

Sicko-Goad L (1982) A morphometric analysis of algal response to low dose, short-term heavy metal exposure. Protoplasma $110: 75-86$

- (1986) Rejuvenation of Melosira granulata (Bacillariophyceae) resting cells from the anoxic sediments of Douglas Lake, Michigan. II. Electron Microscopy. J Phycol 22:2835

Sicko-Goad L, Jensen TE (1976) Phosphate metabolism in bluegreen algae. II. Changes in phosphate distribution during starvation and the "polyphosphate overplus" phenomenon in Plectonema boryanum. Amer J Bot 63:183-188
Sicko-Goad L, Lazinsky D (1982) Polyphosphate in natural phytoplankton assemblages and its formation and degradation in cultured algal cells. USEPA 600/9-82-007. In: Archibald, P (ed) Proceedings of the State-of-the-Art Research Seminar in Environmental Biology, Duluth, MN. US Environmental Protection Agency, Office of Exploratory Research. pp 222-237

Sicko-Goad L, Stoermer EF (1979) A morphometric study of lead and copper effects on Diatoma tenue var. elongattim (Bacillariophyta). J Phycol 15:3i6-321

Sicko-Goad L, Ladewski BG, Lazinșy D (1986) Synergistic ef fects of nutrients and lead on the quantitative ultrastructure of Cyclotella. Archiv Environ Contam Toxicol 15:291-300

Sicko-Goad L, Stoermer EF, Ladewski BG (1977) A morphometric method for correcting phytoplankton cell volume estimates. Protoplasma 93:147-163

Silverberg BA (1975) Ultrastructural localization of lead in Stigeoclonium tenue (Chlorophyceae, Ulotrichales) as demonstrated by cytochemical and $X$-ray microanalysis. Phycologia $14: 265-274$

Smith IW, Wilkinson JF, Duguid JP (1954) Volutin production in Aerobacter aerogenes due to nutrient imbalance. I Bacteriol $68: 450-463$

Smith MA (1983) The effect of heavy metals on the cytoplasmic fine structure of Skeletonema costatum (Bacillariophyta). Protoplasma 116:14-23

Spitznagel JK, Sharp DG (1959) Magnesium and sulfate ions as determinants in the growth and reproduction of Mycobacterium bovis. J Bacteriol 78:453-462

Starr RC (1978) The culture collection of algae at the University of Texas at Austin. J Phycol 14:47-100

Stoermer EF, Sicko-Goad LM, Lazinsky D (1980) Synergistic effects of phosphorus and heavy metal loadings on Great Lakes phytoplankton. USEPA 600/9-80-034, US Environmental Protection Agency, Duluth MN, pp 171-186

Thomas WH, Hollibaugh JT, Seibert DLR (1980) Effects of heavy metals on the morphology of some marine phytoplankton. Phycologia 19:202-209

Tilman D, Kilham SS (1976) Phosphate and silicate growth and uptake kinetics of the diatoms Asterionella formos a and $C y-$ clotella meneghiniana in batch and semicontinuous culture. Phycol 12:375-383

Voelz H, Voelz U, Ortigoza RO (1966) The "polyphosphate overplus" phenomenon in Myxococcus xanthus and its influence on the architecture of the cell. Arch Mikrobio: $53: 371-388$

Watson ML (1958) Staining tissue sections for electron microscopy with heavy metals. J Biophys Biochem Cytol 4:475478

Manuscript received February 28, 1986 and in revised form May 5, 1986. 